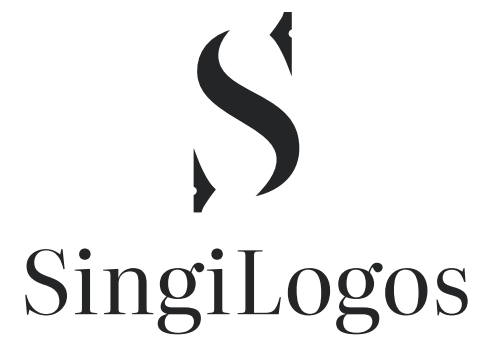

SINGILOGOS 2021, 1(1): 243 - 251

ISSN: 2812-7005

UDK: 378.147.091.32::811.111(497.11)"

2018/2020"

378.147.091.33:784.011.26(497.11)"

2018/2020"

DOI: 10.18485/us_singilogos.2021.1.1.19

Original paper/Originalni naučni rad

\title{
KORIŠĆENJE ADAPTIRANIH TEKSTOVA POPULARNIH PESAMA U NASTAVI SA STUDENTIMA ANGLISTIKE
}

\author{
Jovana Bošković* \\ Univerzitet Singidunum, \\ Beograd, Srbija
}

\begin{abstract}
Apstrakt:
Život u 21. veku podrazumeva veliku izloženost engleskom jeziku u svim sferama počevši od muzike i društvenih mreža a zaključno sa brojnim zabavnim sadržajima kojima smo izloženi putem malih ekrana. Engleski jezik se izučava na mnogim univerzitetima širom sveta. Kako dodatno motivisati studente anglistike nakon što su se već odlučili da studiraju engleski jezik i pored tolike sveopšte izloženosti engleskom jeziku na dnevnom nivou? Muzika je medijum koji je opšteprisutan i veoma popularan među svim generacijama. U skladu sa humanističkim pristupom u nastavi ovaj rad nudi adaptirane tekstove pesama na engleskom jeziku (prerađene tekstove poznatih pesama) koji kada se uvedu u učionicu utiču na pozitivnu atmosferu i podižu motivaciju studenata tokom različitih etapa nastave. Tekstovi prate muziku originalnih pesama dok je tekst izmenjen i prilagođen ciljevima u učionici. Prilaže se opis reakcija studenata kao i jasni razlozi za upotrebu datih tekstova u određenim stadijumima tokom trajanja semestra uz komentar autora o ishodima zadatih ciljeva.
\end{abstract}

\section{Article info:}

Received: June 28, 2021

Correction: July 14, 2021

Accepted: August 7, 2021

Ključne reči:

anglistika,

muzika,

motivacija,

humanistički pristup,

tekstovi,

studenti.

\section{UVOD}

Engleski jezik kao lingua franca zauzima primarnu poziciju u svetu. Engleskim jezikom se koriste ljudi u mnogim sferama počevši od 50-ih godina XX veka kao na primer političari na međunarodnim konferencijama, profesori univerziteta iz različitih zemalja, biznismeni koji žele da prošire posao u inostranstvu. ${ }^{1}$ Danas u Srbiji na svakom koraku možemo videti promovisanje škola za učenje engleskog jezika.

1 Krystal, 2009, 28-30. 
U ovom radu fokus je na studente studijskog programa Anglistika, Univerziteta Singidunum koji su se odlučili da studiraju engleski jezik. Prema definiciji iz Velikog rečnika stranih izraza mediji su sredstvo komunikacije i izražavanja. ${ }^{2}$ Muzika i pesme su upravo jedan od tih medija. Motivacija predstavlja temu o kojoj se puno govori u metodičkim krugovima a posebno u poslednjim decenijama. Nakon definisanja okruženja u kojem se nastava odvija, zatim pregleda tipova motivacije ovaj rad predstavlja adaptirane tekstove postojećih popularnih pesama koje se koriste u nastavi na engleskom jeziku kako bi se poboljšala atmosfera u učionici i poboljšao nivo motivacije te na taj način stvorilo plodno tle za napredak svih studenata. Nakon svakog teksta je predočeno na koji način je pesma obrađena na nastavi, u kom periodu trajanja nastave, reakcije studenata kao i zapažanja autora rada o samom uticaju pesama na atmosferu u učionici i motivaciju studenata.

\section{OKRUŽENJE}

Kako bi se ustanovili okviri o kojem se govori potrebno je napomenuti različita okruženja i tipove engleskog jezika u učionici. Kada se engleski jezik uči kao strani jezik (English as a foreign language - EFL) nastava odvija u zemlji u kojoj engleski nije zvaničan jezik te se razlikuje od maternjeg jezika studenata. Definicija stranog jezika obuhvata sve jezike koje jedan govornik usvoji nakon usvajanja maternjeg jezika uz napomenu da se učenje tog drugog jezika sprovodi u instituciji. ${ }^{3}$ Pored učenja takozvanog opšteg jezika (general English) što je i najrasprostranjeniji tip u školama kako državnim tako i privatnim, potrebno je definisati i studente koji prisustvuju nastavi engleskog jezika za posebne namene (English for specific purposes - ESP) jer su oni ranije definisali razloge usled kojih uče jezik. U tim okvirima se izdvaja i engleski za akademske namene (English for Academic purposes - EAP) koji je sastavni deo posebno osmišljenih kurseva i predmeta u akademskom okruženju. ${ }^{4}$ Insitucija u kojoj se sprovodi nastava o kojoj je reč u ovom radu jeste Univerzitet Singidunum u Beogradu i studijski program Anglistika na predmetu Savremeni engleski jezik 1 i 2 - prevod sa engleskog na srpski tokom akademskih godina 2018/19. i 2019/20, odnosno sa dve generacije studenata.

\section{HUMANISTIČKI PRISTUP U NASTAVI}

Humanistički pristup u nastavi podrazumeva rad sa učenicima pri čemu se pažnja pored materije koja se obrađuje posvećuje i potrebama, osećanjima, nadama, težnjama i iskustvima svih prisutnih u učionici. Humanističko obrazovanje neguje samospoznaju i samopouzdanje kod učenika. ${ }^{5}$ Prema Karlu Rodžersu, kada se učenici nalaze u učionici u kojoj profesor iskazuje razumevanje prema njima tada se stvara povoljna klima za napredovanje. ${ }^{6}$

2 Klajn i Šipka, 2006, 745.

3 Vučo, 2009, 16.

4 Harmer, 2007, 19.

5 Moskowitz, 1978, 14.

6 Rodgers, 1980, 156. 
Smatra se da je potencijal za usvajanje uzdrman u situacijama kada su izrazito negativna osećanja (anksioznist, strah, bes, stres) prisutna u učionici dok se mogućnost za postizanje uspeha povećava ukoliko studenti uživaju u samom procesu učenja. ${ }^{7}$ To su postulati koji su uticali na stvaranje i adaptiranje tekstova koji su glavni fokus ovog rada. Međusobno uvažavanje, poštovanje, pozitivna atmosfera, diskusije o temama koje se obrađuju u nastavi, iskazivanje ličnih stavova, podrška i vredan rad su sastavni deo časova koji su iznedrili pomenute tekstove.

\section{MOTIVACIJA}

Mnogi autori su se bavili terminom i značenjem reči motivacija. Pod motivacijom se podrazumevaju faktori kao što su potreba za istraživanjem, aktivnošću, stimulacijom, novim saznanjima, i ojačavanju ega. ${ }^{8}$ Takođe, motivacija se definiše i kao stanje koje tera čoveka da dela kako bi ispunio neki ranije postavljen cilj bilo putem intelektualnog ili fizičkog napora. ${ }^{9}$ Prema Harmeru postoje dva tipa motivacije koja su prihvaćena od najvećeg broja autora i to su ekstrinzična i intrinzična motivacija. Ekstrinzična motivacija obuhvata spoljašne faktore kao što su želja da se položi ispit, poriv za dobijanjem određene finansijske nadoknade, ili pak otvaranja mogućnosti ka putovanjima. S druge strane, intrinzična motivacija potiče iz samog pojedinca te je sila koja ga pokreće recimo želja da bude bolji ili uživanje u samom procesu usvajanja novih znanja. ${ }^{10}$ Upravo je sam proces usvajanja odnosno jedan od faktora a to je atmosfera na času cilj adaptacije i uvođenje tekstova i pesama na nastavu. Prema Harmeru, izvori motivacije u učionici su sledeći: društvo u kojem živimo, ljudi kojima smo okruženi, nastavnik jezika, metod koji se koristi u nastavi. Izdvojićemo ulogu nastavnika u vidu njegovog stava prema jeziku i procesu učenja jer ukoliko nastavnik pokazuje entuzijazam to u velikoj meri utiče na pozitivnu atmosferu u učionici. Zatim metode koje se koriste u nastavi, poverenje koje učenici ostvare sa nastavnikom i održavanje tog korektnog odnosa takođe utiče na motivaciju u učionici. ${ }^{11}$

\section{ADAPTIRANI TEKSTOVI - PROCES, UPOTREBA I REAKCIJE}

Tokom naših časova pored zahtevnih jedinica koje su obrađivane na nedeljnom nivou uvođeni su i tekstovi pesama kako bi se studentima prve godine studija pružila dodatna podrška i poboljšala atmosfera u učionici. Tokom priprema materijala za nastavu i razmišljanjima o najboljem načinu da se poboljša atmosfera u učionici i omogući što veća produktivnost rodila se ideja o preradi tekstova. Šlušajući muziku na svakodnevnom nivou i razmišljajući o gradivu koje se obrađuje, porukama koje želim studenti da čuju, principima na kojima se zasnivaju časovi tokom naše saradnje i načinima da to postignem prvi stihovi su se takoreći sami javili.

7 Arnold i Brown, 1999, 2.

8 Brown, 2000, 160-166.

9 Williams i Burden, 1997, 120.

10 Harmer, 2003, 51.

11 Harmer, 2003, 52. 
Vremenski period koji je bio potreban za za svaku pesmu se razlikuje i prosek je od tri dana do tri nedelje. Studenti su bili upoznati sa tekstom tek kada bih u potpunsti bila zadovoljna svim porukama koje tekstovi nose. Svaki tekst je podjednako važan i ima svoju svrhu od uvoda i utemeljivanja načina rada, do opuštanja pred kolokvijum i sumiranja atmosfere na časovima tokom celog kursa zatim dodatno ohrabrivanje studenata da i ubuduće nastave vredno da rade uz pozitivan stav prema radu. Pre nastave je nastalo samo prvi tekst dok su svi ostali bili rezultat osluškivanja i praćenja dešavanja u učionici. Prva tri teksta su imala premijeru sa obe generacije studenata dok je četvrta nastala tokom saradnje sa studentima iz generacije 2019/20.

1) Oh, those lovely words

Words as old as time.

True as words can be.

All will become friends

When the lecture ends.

Oh, those lovely words.

Always do a spelling check.

For each text pretty please.

All a little scared.

Everyone must come to class prepared.

Oh, those lovely words.

Tekst se oslanja na muziku iz Diznijevog crtanog filma Lepotica i zver iz 1991. godine, Adaptacija je korišćena na uvodnom predavanju odnosno tokom prvog časa i upoznavanja nove generacije studenata. Pre puštanja ove pesme smo imali diskusiju o njihovim omiljenim filmovima, pesmama pa i animiranim crtanim filmovima čime sam usmerila razgovor i na temu ciljanog crtanog. Ovaj adaptirani tekst ima za cilj da pokaže kako će se tokom nastave iz tog predmeta vredno raditi, da je potrebno da se dođe sa svim materijalima na nastavu, da će fokus biti divne reči engleskog jezika, da je razumljivo što su svi pomalo uplašeni jer su zakoračili u nepoznato ali da su na pravom mestu i da će do kraja kursa svi postati bogatiji ne samo na polju znanja već i na polju prijatelja. Uz tekst koji se prikazuje na projektoru u vidu ppt prezentacije u pozadini ide tiho instrumentalna verzija originalne pesme. ${ }^{12}$ Muzika koja prati tekst je lagana i umirujuća i savršena za uvodni deo. Nakon otpevane pesme studenti su bili vidno iznenađeni ali su osmesi krasili njihova lica. Pesma je bila uvod za razgovor o načinu rada, očekivanjima kako studenata ali i nastavnika a na kraju tog časa ponovo puštam pesmu i svi zajedno pevamo jer su i studentima reči dostupne na projektoru. Komentari studenata na prvo izlaganje prilagođenih tekstova jeste da se do tada nisu susreli sa takvim načinom rada i da to zaista nisu očekivali kada su došli u učionicu ali da su oduševljeni i da se posebno raduju najavi da je to samo početak. 


\section{2) Trans/ation, translation}

Translation, translation! What a wonderful word.

Translation, translation! We'll stick together like a flock of birds.

It means no spelling mistakes for the rest of your days.

It's translation problem-for-each philosophy.

Translation, translation!

Tekst se oslanja na muziku iz Diznijevog crtanog filma Kralj lavova iz 1994. godine, Adaptacija je korišćena pred prvi kolokvijum kako bismo se podsetili da je individualni doprinos svakog studenata u vidu mogućih rešenja za prevod od velikog značaja u cilju napretka svakog pojedinca i kao podsetnik da će se posebna pažnja na testiranju posvetiti pravilnom pisanju uz fokus na timski rad i međusobnu saradnju unutar timova tokom rada na času. Pored toga, ovaj tekst je namenski kako bi se ispunilo obećanje da će na određeni vremenski period u naša četiri zida stići razigrane reči koje ćemo imati priliku zajedno da otpevamo uz muziku iz originala. ${ }^{13}$ Iščekivanje teksta a zatim i pevanje istog na kraju časa podiže atmosferu na najviši nivo i student uz osmeh iščekuju testiranje naredne nedelje.

\section{3) I'm gonna translate}

$1^{\text {st }}$ year has passed and my life is great.

I've managed to get up that great big hill of hope for the best translation.

I realized quickly that I did my best when I came to classes with my lovely peers. Oh, man since we're all like family here.

And so I write sometimes when I'm lying in bed

Just to get it all out what's in my head,

And I, I'm feeling a little creative.

And so I wake in the morning and I take that text

And I take all the resources and thesaurus

And I scream from the top of my lungs

WHICH OPTION'S THE BEST?

And just start to tra - $\mathrm{a}-\mathrm{a}-$ anslate!

Tra - a - a - anslate!

And I tra

I, I translate! $\times 2$

Oh, oh, oh, oh, oh, oh, oh, oh, oh, oh, oh, oh

And I try

Oh my God do I try

I try all the time

In this amazing institution

And I pray oh my God do I pray

I pray not to stir away

From the original! 
Tekst se oslanja na muzičku numeru What's up ${ }^{14}$ američkog rok benda 4 Non Blondes iz San Franciska (1989-1994.) Adaptacija ovog teksta je iskorišćena na poslednjem predavanju sa generacijom 2018/19. kao suma sumarum rada tokom cele godine. $U$ ovom tekstu studenti se pohvaljuju za sav vredan rad tokom godine koji im je omogućio da prebrode svaku jezičku poteškoću i nedoumicu sa kojom su se susreli uz napomenu korišćenja različitih rečnika i fokusiranost na svaki deo rečenice kako bi se uvek pronašla najbolja opcija pri prevodu sa engleskog na srpski jezik i kako bi se zadržalo značenje iz izvornog teksta i u tekstu prevoda. Još jednom se naglašava timski rad i međusobna saradnja tokom nastave u cilju konstantnog napretka i usvajanja novih saznanja u pozitivnoj i raspevanoj atmosferi. Ovaj tekst je takođe i pozdrav jer se predavanja završavaju kao i naša saradnja tokom godine. Studenti su bili obavešteni unapred da ćemo kraj nastave obeležiti kao što mogu da i očekuju pesmom nakon čega će nastaviti saradnju sa kolegama u narednim godinama studija. Studenti su iskazali veliko oduševljenje načinom na koji smo završili nastavu i to je zaista bio jedan veliki emotivni naboj kako za student tako za autora rada.

4) It's all about that text

Because you know we're all about that text

'Bout that text, translation

We're all about that text

'Bout that text, translation

We're all about that text

'Bout that text, translation

We're all about that text

'Bout that text... text... text... text

Yeah, it's pretty clear, that we've been working hard

But we can do it, do it, like we're supposed to do

'Cause we got that grammar and rules, texts and will

to put all the right words in all the right places

We see those dictionaries

No Google translate please

We know that isn't so good, come on now, make it stop

You know that you'll get there solely if you try

And I'll support you every day from the beginning 'till the end

Yeah, your parents they told you go study my lovely child

(Shoo wop wop, sha-ooh wop wop)

We are waiting for you to go on and become a star

(Go study, uh, go study, study)

You know it won't be so easy but don't worry we've got your back

(Shoo wop wop, sha-ooh wop wop)

14 https://www.youtube.com/watch?v=6NXnxTNIWkc 
So if English is what you're into at Singidunum is your blossom time

Because you know we're all about that text

'Bout that text, translation

You can be the best,

Be the best, translation

You already are the best

Are the best, translation

Always do your best

Do your best, do your best, best, best, best.

Tekst je zasnovan na pesmi All about that bass iz 2014. godine koju izvodi pevačica Megan Trejnor. Adaptiran tekst je iskorišćen u cilju umanjenja anksioznosti neposredno pred ispitni rok za generaciju 2019/20. a posebno sa osvrtom na vredan rad i trud koji su studenti ulagali na nedeljnom nivou tokom trajanja nastave. Studenti se pozivaju da obnove sva pravila o kojima je govoreno, da u daljem radu obilato koriste rečnike, da su ih roditelji sa velikim nadama ispratili na fakultet u želji da postanu veoma uspešni a da su došli na pravo mesto kako bi to i ostvarili jer imaju podršku na tom putu sa svih strana. Poslednjih par stihova ističu da se studenti i ubuduće uvek trude i daju sve od sebe kako bi bili najbolji u tome čime se bave, što je u ovom datom slučaju prevođenje sa engleskog na srpski jezik, a da su u našoj učionici već pokazali da imaju potencijal da da zaista jesu najbolji. Sa takvim krajem se studenti ispraćaju u narednu godinu studija, sa pozitivnim stavom i porukom da nastave vredno da rade i ubuduće. Nakon što smo razgovarali o originalu odslušali smo samo instrumental ${ }^{15}$ uz prezentovanje adaptiranih stihova. Zatim je usledilo zajedničko pevanje teksta sa prezentacije. Posle zabavnog dela smo i porazgovarali o svim porukama koje pesma nosi, o podršci roditelja, prijatelja, profesora, o strahovima kako će izneti sve što ih čeka, i o veri da uz vredan rad i trud rezultati moraju doći.

\section{ZAKLJUČAK}

Engleski jezik je prisutan u svakodnevici skoro svih ljudi u našem bliskom okruženju. Određen broj mladih ljudi se odlučuje da im to bude profesija. Svrha ovog rada jeste da pokaže dobar primer iz prakse kako dodatna motivacija od strane nastavnika i humanistički pristup u nastavi u visokoškolskoj ustanovi može poboljšati atmosferu u učionici i dodatno motivisati studente za rad i napredak. Taj cilj je postignut uvođenjem adaptiranih tekstova već poznatih pesama na nastavu, pevanje i razgovor o datim tekstovima. Studenti obe generacije su veoma pozitivno i razdragano prihvatili ovaj način rada, tekstove i ohrabrenje da rade što bolje i u što pozitivnijoj atmosferi. Na osnovu atmosfere tokom nastave može se jasno zaključiti da su od prvog teksta kojem su bili izloženi, zatim preko iščekivanja novih tekstova, njihovog prezentovanja, razgovora o glavnim porukama istih zaista napravili veliku razliku u zalaganju na času kao i celokupnoj atmosferi tokom rada od samog početka, zatim kolokvijuma i do kraja nastave pred ispit. 
Studenti su pored novih saznanja i vrednog rada na nastavi imali i osećaj pripadnosti grupi, osećaj podrške i pozitivnu atmosferu od trenutka kada uđu u učionicu do kraja saradnje tokom godine. Tekstovi su dali jednu potpuno novu dimenziju koja je obeležila saradnju sa obe generacije studenata.

\section{BIBLIOGRAFIJA}

Arnold, J., Brown, D. (1999): A map of the terrain. In J. Arnold, (Ed.), Affect in Language Learning (pp. 1-24). Cambridge: Cambridge University Press

Brown, H. Douglas (2000): Principles of Language Learning and Teaching, $5^{\text {th }}$ edition, London: Pearson Education Ltd

Vučo Julijana (2009): Kako se učio jezik. Beograd: Pogled u istoriju glotodidaktike od prapočetaka do Drugog svetskog rata

Krystal David (2009): English as a global language, $2^{\text {nd }}$ edition. Cambridge: Cambridge University press

Klajn I., Šipka M. (2006): Veliki rečnika stranih izraza, Novi Sad: Prometej

Moskowitz Gertrude (1978): Caring and Sharing in the Foreign Language Class A Sourcebook on Humanistic Techniques, Boston: Heinle \& Heinle Publishers

Rodgers Carl (1980): A Way of Being, New York: Houghton Mifflin Company

Harmer Jeremy (2007): The practice of English language teaching, $4^{\text {th }}$ edition, London: Longman publishing

Harmer Jeremy (2003): The practice of English language teaching, $3^{\text {rd }}$ edition, London: Longman publishing

Williams, M., Burden, R. (1997): Psychology for Language Teachers, Cambridge: Cambridge University Press

https://www.youtube.com/watch?v=mAaiVIKkZzE Beauty and the beast, Instrumental Philharmonic Orchestra

https://www.youtube.com/watch?v=3jQIIXuhsC8 Hakuna Matata, Lion King

https://www.youtube.com/watch?v=6NXnxTNIWkc 4 Non blondes, What's up

https://www.youtube.com/watch?v=oLShwvZopls 4 Non blondes, What's up, karaoke verzija

https://www.youtube.com/watch?v=7PCkvCPvDXk Meghan Trainor, All about that bass

https://www.youtube.com/watch?v=vH36ubkIzWM Meghan Trainor, All about that bass official instrumental version 


\section{USE OF ADAPTED TEXTS OF POPULAR SONGS IN TEACHING WITH ENGLISH STUDENTS}

\begin{abstract}
Summary:
Living in today's day and age means that we are surrounded by the English language everywhere we go. Many young people decide to study the English language, choosing it as a profession. The idea from which this paper originated is the question of how to additionally motivate English language students since they have already chosen it and are surrounded by the language via different types of media available on a daily basis. The idea to create a positive and nurturing atmosphere in the classroom so that, besides the hard work and the new knowledge provided, students can also feel supported and motivated, improve team work and develop a sense of belonging to the group of their peers at the university of their choice. In this particular instance, they are first-year students of the study programme Anglistics at Singidunum University in Belgrade, Serbia. The classes in question are Contemporary English Language 1 and 2 - Translation from English into Serbian. The tool for achieving such a positive, collaborative and nurturing atmosphere is introducing adapted lyrics of famous songs in English. The author of this paper wrote those lyrics and introduced them in her classes at Singidunum University at different stages of the course with a specific purpose. The first text is to set the tone and to introduce the students to the way of working in the classroom, the second, third and fourth are used to tackle anxiety before a testing period, to provide additional support and to emphasize the importance of working hard, using relevant sources and striving to be great. According to the observations of the author, the texts made a significant difference and improved the atmosphere in the classroom and student motivation.
\end{abstract}

